Teologia i Moralność, volumen 16(2021), numer 2(30)

doi: 10.14746/TIM.2021.30.2.11

ORCID: 0000-0003-1383-1754

ANDRZEJ PAWŁUCKI

Akademia Wychowania Fizycznego we Wrocławiu

Zakład Pedagogiki Kultury Fizycznej

\title{
Ukostiumowienie płci i dekonstrukcja kostiumu jako znaku tożsamości płciowej. Refleksja humanisty, pedagoga kultury fizycznej ${ }^{1}$
}

\section{Wstęp}

Kostiumowe okrycie ciała było i pozostaje do dziś zaprzeczeniem nagości, a tym samym utajnieniem płciowych intymności. Nawet więcej - od zaprzeczenia nagości płciowej zaczęło się kostiumowe utajnienie naturalności („ulistnienie” ciała utajniało przydatki płciowe, a nie było maskowaniem twarzy), co w codzienności sprowadza się do trywialnej czynności „utajnienia” przydatków płciowych spodnim odzieniem, a w drugiej kolejności wierzchnim okryciem całości połaci skórnej (bywa, że tylko pojedynczym, a w chłodnym otoczeniu - wielowarstwowym); w codzienności współczesnej (w odróżnieniu od czasów Adama i Ewy, od początków rodzaju ludzkiego, w których ani przedmiot bielizny, ani tym bardziej jego idea nie był znany) utajnienie nagości płciowej nie znosiło różnicy, a tylko czyniło niewidzialną ,różność” płciową. Dorośli posiedli możność dojrzałego poznania siebie. Nie byli jak dzieci, które w swej strategii czynienia siebie niewidzialnymi okrywają się kołdrą albo twarz samą w dłoniach skrywają; co by prowadziło do wyjaśnienia - w myśl teorii dwukierunkowości - że sama utrata wzrokowej relacji (widzenia drugiego) w przeświadczeniu dziecka, czyni je właśnie niewidzialnym (jak drugiego nie widzę, to mnie „nie ma”, jestem niewidzialny).

Pierwsi rodzice złudzeń nie mieli, że nie są tacy sami, jakkolwiek nie to mieli na myśli, żeby utajnić nagość w całości, lecz by właśnie znaki szczególne swej

\footnotetext{
${ }^{1}$ Z rozdziału przygotowywanej monografii Homo Physicus (2022).
} 
fizyczności - stanowiące o różności płciowej obojga - uczynić niewidzialnymi. Całą „resztę” ciała uwidocznili, a tylko znacząco istotny fragment dla nich samych - ten wstydliwy właśnie - zakryli. Nie schowali więc w dziecięcym stylu twarzy w dłoniach z przeświadczeniem, że znikają z pola widzenia obcego świadka ich nagości, lecz całkiem realistycznie płciowe przydatki ciała utajnili. I nie o utajnienie płciowości im chodziło - gdyż zataić nie mogli, że przez zarost u jednego, a piersi u drugiej pozostają mężczyzną i niewiastą - ale o zaprzeczenie tej warstwy nagości, która najbardziej zawstydza, wprawia w zakłopotanie przed obcym.

\section{Inspiracje antropologii sumeryjskiej i biblijnej dla postrzegania płci w kulturze euro-atlantyckiej}

Świadek ich upublicznienia nie tylko wiedział o ich płciowej odmienności (kto, jak nie On, powołał niewiastę do istnienia), ale świadomie do niej doprowadził - w oczekiwaniu na prokreacyjne samospełnienie. Dodajmy, że wszyscy ich poprzednicy z laboratorium w Abzu byli bezpłodni; pozbawieni chromosomu 232, determinującego nie tylko płeć, ale upełnomocniającego do spełnienia się w prokreacyjności; nie mogli mieć potomstwa. I kto, jak nie oni, Enki i Ninharsag znający prawo powiernictwa życia (przez dorosłych potomkowi) i dziedziczenia życia (przez potomka od rodziców) - rozumieli, że bytowanie człowieka dokonuje się przez nieoddzielne połączenie relacją seksualności mężczyzny z niewiastą. Nigdy inaczej. Enki, na znak, że widzi ich jako różnych, lecz takich samych, bo stanowiących jedność, obdarowuje ich kostiumami: mężczyźnie przydziela brązowy (wszak z gliny go „ulepił”3), a kobiecie biały - już to przez wzgląd na biel jej włosów, już to raczej - na oblubieńczą niewinność, a może z tego tylko powodu, że płócienno-lniana biel materiału była bardziej dostępna. Kostium utajniał cielesną naturalność, a przez znak barwy mu przydany określał naturalną płciowość, co miało zaświadczać także o prokreacyjnej zdolności obojga, czyli - w rzeczy samej - gotowości poczęcia życia nowego. Kostium mężczyzny i niewiasty zaświadczał znakowo o udziale obojga w kulturze życia. U kresu czasu kostium będzie unieważniał płciowość, stając się znakiem sprzeciwu seksualistów wobec samej idei prokreacyjności (płciowość - nie, seksualność - tak; rodzicielstwo - nie,

\footnotetext{
2 Przedstawiana tu wizja antropogenezy, znana z sumeryjskiej mitologii za sprawą publikacji Zecharia Sitchina (2018), nie jest sprzeczna $\mathrm{z}$ biblijną opowieścią o stworzeniu człowieka, zawartą w Księdze Rodzaju.

${ }^{3}$ Ulepienie z gliny pozostaje tajemnicą, kiedy uwzględni się tylko biblijną wersję aktu stworzenia (ukształtowania) człowieka. Zgoła inaczej, czyli racjonalniej, można podejść do sprawy, kiedy uwzględni się pierwiastkowo-chemiczny skład naczyń laboratorium genetycznego, które były $\mathrm{z}$ różnym skutkiem stosowane $\mathrm{w}$ dawnych, przedpotopowych procedurach łączenia materiału genetycznego hominida z nasieniem Nefilim (Sitchin, Zecharia. 2018. Kroniki Anunnaki. Warszawa: Wydawnictwo Amber, 151).
} 
partnerstwo w homoseksualności - tak), co w konsekwencji zjednoczy tęczowych seksualistów ponowoczesności z czarnymi aborcjonistami feminizmu w paradzie ku cywilizacji śmierci.

\section{Zanegowanie binarnego logosu płci w ideologii gender}

Od tej chwili pradziejów w Sumerze: ukostiumowienia płci wraz z przydaniem odzieniu znaku-koloru męskości i kobiecości - projektów kostiumowych dla obojga będzie nieskończenie wiele, lecz nie zawsze bezwzględnie tak samo konsekwentnie uwzględniających dualność płciową człowieka ${ }^{4}$. Co będzie wskazywało na manipulację kulturową na naturze cielesnej przyrodzoności; aż w „końcu”, u kresu czasu - gdyby za kres uznać wywrócenie znaku kostiumu „do góry nogami", jako jego postmodernistyczną dekonstrukcję - dojdzie do negacji wszystkiego: prawdy o prawdziwej płciowości, męskości, kobiecości, ojcostwie i macierzyństwie - o człowieczym sposobie istnienia we wspólnocie życia; w rezultacie następuje „śmierć Boga” (Nietzsche 1881), „koniec historii” (Fukuyama 1989), „koniec człowieka” (Fukuyama 2004), „koniec ludzkości” (Godin 2004); jakby wszystko, co przytrafiło się człowiekowi na początku jego dziejów - a przytrafił mu się dar życia, z którego sam mógł życie wyprowadzać, by powierzyć je potomstwu - mogło być unieważnione przez człowieka okrutnego - niszczyciela życia cudzego, który został dziedzicem życia, a innych prawa do życia pozbawiał (skazując na śmierć w obozach zagłady ludzkości, zadając śmierć poczętym, a nienarodzonym, czy uśmiercając jeszcze żywych, a już zbędnych).

Człowiek jest życiem w sobie, bo jest bytem osobnym (mężczyzna osobnym i niewiasta osobnym), lecz by wzbudzić życie potomka (wszczynając relację powiernictwa życia), mężczyzna z niewiastą muszą istnieć nieoddzielnie w relacji seksualności. I tylko w tej relacji pozostając - w jedności dwojga osobnych bytów różnopłciowych - są metafizycznie prawdziwi. Inna relacja: byt osobny w relacji „,do siebie” lub dwa byty równopłciowe w relacji „,ku sobie” - jako niepodobieństwo przyczynowości prokreacyjnej - jest fałszem metafizycznym; co znaczy po prostu, że takiej relacji nie ma. Gdyby była, polegałaby na niezgodności bytu płciowej prokreacyjności człowieka z ideą siebie (kto by twierdził, że jest, urągałby czystej rozumności człowieczej istoty, a swojej własnej wystawiałby świadectwo poznawczej ułomności: matołectwa czy idiotyzmu) (por. Dogiel 1992). ${ }^{5}$ A ponieważ takiej relacji w ogóle nie ma, to i życia być nie może w ciągłości

\footnotetext{
${ }^{4}$ Odwołuję się do artystycznej wizualizacji (nieznanego malarza) aktu wręczenia Adamowi i Ewie kostiumów w kolorach jasnego brązu i bieli (obraz w wersji elektronicznej w posiadaniu autora).

5 „Fałsz metafizyczny, gdyby istniał polegałby na niezgodności rzeczy z rozumem. Fałszu metafizycznego nie ma, ponieważ każdy byt, wszystko co istnieje jest prawdziwe" (Dogiel 1992, 87).
} 
międzypokoleniowej, gdyż przyczyna prokreacyjności, która je konstytuuje, nie istnieje.

Co znaczy z logicznego punktu widzenia, że najmniejsze zakłócenie prokreacyjnej przyczynowości - regulacjami eugenicznymi „czyścicieli rasy”6 - czy tylko zawieszenie na skutek działań wojennych, nie mówiąc - zniesienie przez ideologicznych uzurpatorów (,wersji” gender i queer) panowania nad naturą płci cielesnej człowieka - musi skutkować ustaniem życia człowieczego.

A zatem, ujmując imaginatywnie następstwo pogwałcenia rozumności prawa naturalnego (ius naturalis) przez fałszywych antropologów, którzy unieważniają zaklęciem ideologicznym istotową różnicę płci męskiej i żeńskiej, a nawet stają się repulsywni, kiedy słyszą od uczonych, iż to nie w kulturze zawiera się siła przyczynująca płeć - trzeba im przypomnieć, że różnica genetyczna różnicuje ontycznie człowieka, z czego bierze się podział człowieka na mężczyznę i kobietę. Podział jedynie możliwy - gdyby pominać przypadki istot ułomnych genetycznie (wyjaśniane aberracjami strukturalnymi chromosomów i mutacjami genowymi) i jedynie prawdziwy metafizycznie. Różnica płci cielesnej należy do istoty natury człowieka, jak cała jego przyrodzoność i nadprzyrodzoność, co tłumaczy, dlaczego człowiek bytujący w sobie dwojako ma moc przemieniania swoich przypadłości, czyli walorów istnieniowych (dzięki aktom wolnej woli i rozumnej duchowości), a nie cech istotowych. Nie leży w jego mocy przemiana konstytutywnych cech istotowych.

Stąd wynika, że człowiek zastaje siebie jako byt dualnie zróżnicowany, a płeć cielesna, jako stała ontyczna, stanowi o różnicy między męskością a kobiecością - nieodwracalnej w znaczeniu strukturalnym oraz nieodwołalnej w znaczeniu ideologicznym. Zaklinacz natury, który uroił sobie, że w jego mocy leży dowolne, dyskursywne ustalanie płci, a nawet kulturowe ,zatwierdzanie” prokreacyjności, nie „odwoła” u kobiety jej kobiecości i nie powoła do męskości, kiedy kobiecość została jej determinacyjnie zadana, u samych podstaw genetycznych jest jej „zapisana” (co komu ,pisane” - jako przeznaczenie genetyczne - takim pozostać musi).

Wszystko, co uczyni ów zaklinacz wbrew płciowej istności człowieka (o ,zadanej” mu męskości lub kobiecości), wzbudzi patologię społeczną, a w dalszej konsekwencji osłabi przyczynowość międzypokoleniowego samostanowienia społeczeństwa jako wspólnoty życia. Człowiek ten rozchwiany moralnie, bo nieuzdolniony do uczestnictwa we wspólnocie życia, będzie głosił, że ma takie samo prawo do życia; gdzieś usłyszał, że pod tym względem wszyscy są sobie równi. Odmówi innym udziału w kulturze życia od naturalnego poczęcia do naturalnej śmierci, uznając uprawnienie do aborcji i eutanazji na życzenie za spełnienie po-

${ }^{6}$ Określenie „czyściciele rasy” stanowi podtytuł monografii Macieja Zaremby-Bielawskiego. 2011. Higieniści. Z dziejów eugeniki. Wołowiec: Wydawnictwo Czarne. 
stulatu wolności samostanowienia, zaś przeciwników uśmiercania obłoży karą za powoływanie się na klauzulę sumienia - sobie zaś przypisze prawo przysposabiania życia dziecięcego. Świadomie czy nie, sprzeniewierza się prawu życia przez odmowę udziału w prokreacyjności, a „pod siebie” pisze prawo wbrew prawu (prawo pozytywne w sprzeczności logicznej wobec prawa naturalnego - ius naturalis), by przez nieuczciwy rozum, ulokowany w sprytnie zamaskowanej ideologii pozoru miłosierdzia, zawładnąć życiem dziecięcej niewinności. Prawo pozytywne seksualistów w wersji homo, jest bezprawiem w świetle wieczystego prawa naturalnego heteropłciowej ludzkości.

Ideologowie współczesności, a dokładniej ponowoczesności - rzecznicy rzeczywistości społecznej, w której „płynność” uchodzi za ontologiczną zasadę istnienia (jak niegdyś w surrealizmie, w którym normą było uniezależnienie się od reguł logicznego myślenia) - są zdania, że różnice płciowe muszą być zniesione, a zatem „kto jest mężczyzną, kto jest kobietą, może być [...] odwołane, zaprzeczone"7. A wszystko dla zasady: uprawnienia do dowolnej celebracji różnic każdej inności; każdy jest równy wobec prawa do ekspresji „różności”, dowolnej rozmaitości, a więc także swobodności w czynnym wyrażaniu sprzeciwu wobec naturalności - nawet tej, która przez swoje wewnętrzne uprzyczynowanie determinuje naturę przyrodzoności, a tym samym w sposób konieczny określa istotowość cielesnej płci. Co zatem zostaje zdeterminowane matrycą esencjalnej różności - a płeć cielesna spod takiej matrycy genetycznej „wychodzi” jako „męskość” i „kobiecość" bytu osobnego, właśnie różnego istotowo (niezmienialnego aktem woli ani aktem czynu) - podlegać może ,upłynnieniu”.

Tak mówią ideologowie gender, którzy uznają kulturowość, a nie przyrodzoność, za źródło nabywania tożsamości płciowej ku męskości albo kobiecości, lecz - co ważne - w zaprzeczeniu do ,zastanej w sobie” cielesnej seksualności (co skutkuje dowolną zamianą seksualności „,Z wykorzystaniem” przyrodzonej płciowości cielesnej: przydatki męskie przydają się w konstruowaniu tożsamości kobiecej, a kobiece przydatki w rozpoznawaniu w sobie męskości - oczywiście w parach wyłącznie homoseksualnych); i ideologowie queer - postulatorzy dziwactw seksualnej ekspresji, którzy w ogóle zaprzeczają, by przyrodzoność normowała płciowość, kwestionują istnienie płciowości kulturowej (ustanowiona kulturowo „męskość” i „kobiecość” jest fikcją); w zamian postulują post-płciowość, czyli konstruują seksualność z premedytacyjnym zatarciem tożsamości płciowej. Seksualista w wersji homo nie nazywa się homopłciowcem, gdyż albo płciowość mistyfikuje, albo się jej wyrzeka, zaś seksualność właśnie wychwala

${ }^{7}$ Tak mówił abp Marek Jędraszewski o ideologii gender i pochodzącej z niej ideologii LGBT: ,już nie wiadomo kto jest mężczyzną, a kto jest kobietą, może być w każdym momencie odwołane, zaprzeczone. Nie liczy się nawet to, co o człowieku mówi biologia [...]" (kazanie wygłoszone 20 stycznia 2020 r. w Krakowie). 
i ekspresyjnie ją uwidocznia. Queer nie legitymuje się płciowością, seksualnością - tak, aż do granic absurdu znakowej niezrozumiałości (choć absurdem jest już seksualność „wypreparowana” z płciowości).

Heteropłciowa postać w męskości lub kobiecości nie opowiada światu, że jest heteroseksualna, gdyż wiadomo, że musi być, skoro płciowość określa jej tożsamość cielesną jako kobiety lub mężczyzny. U seksualistów w wersji homo nie wiadomo, kto kim jest w następstwie zacierania przez nich naturalnych „śladów” przypadłościowych płci, które i tak wyjść na jaw muszą na skutek nieugiętej pod naporem kultury ekspresji genów. Kostiumowa mistyfikacja genetycznie zdeterminowanej płci wzbudzi zapewne zachwyt widowni parada love - jak w cyrku, w którym iluzjonista-mag pozoruje mniej czy bardziej udanie wielkość cudotwórcy (przebiera się za kogoś, kim nie jest) - a zaniepokoi parodiowaniem miłości każdą wspólnotę życia w ojcostwie i macierzyństwie, w której miłość do narodzonych i poczętych jest racją moralną ich poświęcenia.

By oczekiwaniom zbuntowanego wobec racjonalności czystego rozumu ideologa politycznej poprawności mogło stać się zadość, na straży jego postulatu znoszenia różnic dla równości wobec prawa do wolności urealnienia każdej imaginacji (nikt nie pyta, o jej chore urojenia) staje strażnik z urzędu administracji państwowej: władzy ustawodawczej, wykonawczej i ostatecznie egzekucyjnej - w uniformie policjanta. Wbrew wszelkim zasadom filozofii bytu (a zwłaszcza tożsamości), racji dostatecznej, prawdziwości i przyczynowości bytu, pojęcie człowieka jako bytu osobnego w męskości i żeńskości, istotowo zróżnicowanego płciowo, a osiągającego kompletność w jedni prokreacyjności, zostaje zastąpione fałszywą konstrukcją logiczną (ideologie mają to do siebie, że prawdę logiczną zastępują dobrze „podrobionym” falsyfikatem, przez co sprawiają pozór naukowości).

Pozór naukowości stwarza ,gender theory” - ideologia w najczystszej postaci, która zawiera w swej konstrukcji logicznej „brudne” - metafizycznie fałszywe - pojęcie człowieka. W rzeczywistości ludzkiej nie ma takiej rzeczy, która uchodzi w tej ideologii (pseudonauce) za prawdziwą. Jak ułomni poznawczo muszą być uczeni, którzy ideologii gender nadali status nauki. A swoją drogą należy zadać im pytanie, dlaczego nie dostrzegli socjologii ciała - nauki empirycznie ugruntowanej - w której zależność tożsamości płciowej od społeczeństwa kultury jest uznanym teoretycznie i metodologicznie kierunkiem badań.

\section{Ocalić istnienie czlowieka rozumnego przez powrót do realistycznej antropologii}

W płynnej ponowoczesności każdy może dokonać wyboru płci cielesnej wedle wyobrażonej tożsamości (nikt nie zadaje pytania uzurpatorowi o przesłanki 
pojęciowania własnej płciowości), z pominięciem natury własnej przyrodzoności. Ideologowie gender, nadużywający dla swych pokrętnych rozważań nazwy „teoria”, twierdzą, że człowiek nie rodzi się jako byt upłciowiony cieleśnie na męskość albo kobiecość, czyli nie rodzi się jako mężczyzna lub niewiasta. Nie przyjmują empirycznie ugruntowanej teorii, że o istotowej różnicy płci „rozstrzyga" determinująco genetyczna matryca. Za nic mają "szkiełko" uczonego, a zwłaszcza metafizyczne „oko” filozofa, który, posługując się zasadą wyłączonego środka, w zastosowaniu do różnicy tożsamości płciowej bytu przypomniałby ideologom, że „albo byt jest, albo niebyt; albo coś jest, albo nie jest; między bytem, a niebytem nie ma czegoś trzeciego" (Dogiel 1992, 41). Mimo prostoty tej zasady w tworzeniu pojęcia mężczyzny i kobiety „teoria” gender w wersji queer doprowadza do absurdu rozróżnienie osobności bytu. Jak pisze Maciej Olczyk, „postuluje zupełne zaniechanie rozróżnień na kobiecość i męskość, uważając za czyste konstrukty społeczne, w dodatku nieuzasadnione żadnym obiektywnym faktem" (Olczyk 2014, 23).

Kobieta i mężczyzna są bytem jedynym w swym rodzaju, ale nie takim samym w osobności. Jako byty osobne są ukonstytuowani wedle idei swej cielesnej płciowości: męskiej i żeńskiej; każde z nich jest zgodne z sobą (tożsame sobie ciałem płciowym) i mimo różnic - a raczej dzięki temu, że są płciowo różni stają się ,jednią bytu”, kiedy zawiązują relację prokreacyjności. Relacji tej nie należy mylić z seksualnością, gdyż racją aktu prokreacyjnego jest powiernictwo życia potomstwu - „,iebie dla kogoś” (czemu przyświeca altruizm) - zaś racją aktu seksualnego jest hedonistyczne powierzenie ,siebie dla siebie” (co wskazuje na egoizm).

„Jednia bytu”, związana prokreacyjnością, uwspólnia istnienie mężczyzny i niewiasty, gdyż to, co zaczęło ich łączyć z potomkiem, jest dobrem ontycznym życia realnego: nie idea życia, lecz samo życie potomka, które z ich życia zostaje poczęte. Życie potomka uwspólnia istnienie mężczyzny i niewiasty, przydaje obojgu godności rodzicielskiej. $Z$ osobności życia obojga następuje przejście do jedni oblubieńczej (o czym przesądza prokreacyjność), a następnie - wraz z przyjściem potomka na świat - wspólnoty rodzinnej (co już jest spełnieniem zasady ciągłości życia i zapowiedzią jego kontynuacji). Wychodząc z relacji osobności ku uwspólnionej prywatności, mężczyzna i niewiasta upubliczniają się, kiedy pierwszym świadkiem ich istnienia staje się pierworodny dziedzic życia. To, co łączyć zaczęło darczyńcę życia z biorcą życia jako potomkiem, było samo życie dobro uwspólnione; ono czyniło człowieka w następnym pokoleniu takim samym bytem: osobnym w męskości i tak samo osobnym w kobiecości oraz tak samo powołanym do kompletowania siebie w jedni prokreacyjności; potomkowie, kiedy matkę i ojca opuszczają, stają się jednym ciałem (,,[...] opuści człowiek ojca swego i matkę i złączy się ze swoją żoną, i będą oboje jednym ciałem. A tak już nie są dwoje, lecz jedno ciało" (Mt 19,3-12)). 
A zatem człowiek to wspólnota życia. Człowiekiem w istnieniu nie jest więc mężczyzna - byt wprawdzie osobny, ale niekompletny, dopóki relacji prokreacyjnej z niewiastą nie zawiąże; nie jest tak samo człowiekiem kompletnym w istnieniu niewiasta, kiedy dla siebie na wyłączność pozostaje (co i tak nie jest logicznie prawdziwe, zaś w rzeczywistości jednostkowo zdarzyć się może, jak w klauzurowym zakonie), ani też człowiekiem kompletnym w istnieniu nie będzie potomek obojga, który dług życia zaciągnąwszy u swoich rodziców, sam nie zawiązałby prokreacyjnej relacji powiernictwa, mimo że spłacie daru życia sprzyjało pokojowe współistnienie ${ }^{8}$.

\section{Kim jest człowiek?}

Co zatem różni człowieka gender i queer - postaci kulturowo i post-kulturowo ustanowionych (najpierw płciowo zdekonstruowanych, a następnie konstruktywistycznie wymyślonych) - od człowieka metafizycznie prawdziwego, czyli bytującego w swojej substancjalnej męskości i kobiecości, zgodnie z realistycznym postrzeganiem siebie.

Pytanie można zadać inaczej - który człowiek jest logicznie prawdziwy, a który fałszywy?:

a) czy człowiek istotowo różny pod względem płciowym ${ }^{9}$, a więc bytujący osobno w przyrodzoności cielesnej jako mężczyzna lub jako kobieta i dzięki temu władny prokreacyjnie (co jest szczególnie doniosłe dla zachowania ciągłości życia rodzaju ludzkiego, zważywszy na przypisaną każdemu śmiertelność ${ }^{10}$ ); przydający sobie tożsamości płciowej zgodnie z zastanym w sobie upłciowieniem cielesnym,

b) czy człowiek różny wprawdzie pod względem płci cielesnej, lecz tożsamościowo niezgodnej z istotą przyrodzoności płciowej mężczyzny i kobiety

${ }^{8}$ Odróżniam potencjalność od aktualności istnienia, a nie samej istoty mężczyzny i kobiety. Potencjalnie każdy człowiek istnieje jako mężczyzna albo jako kobieta, zaś aktualnie niekoniecznie. Zarówno o człowieku jako mężczyźnie, jak i o człowieku jako kobiecie - a raczej: o człowieczej męskości i człowieczej kobiecości - przesądza aktualność ich prokreacyjnego istnienia.

${ }^{9}$ Kobieta i mężczyzna różnią się między sobą, a stanowią jedność człowieka. Nie różnią się jednak „na tyle”, by wielość, a nie dwojakość bytów, stanowiła o jedności człowieka. W ideologii queer jest to jednak możliwe, choć nikt nie zauważa, kto pokłada w niej swoje nadzieje, że jest sprzeczne z zasadą tożsamości bytu; a w tym przypadku - tożsamości fizycznej bytu (niezmiennym co do istoty, a zmiennym co do przypadłości).

${ }^{10}$ Czy człowiek rozumiejący siebie, zdolny do samopoznania - dzięki oczywiście rozumności, która należy do jego istoty - nie musi zadać sobie obowiązkowo pytania (jako byt świadomy udziału w nieuniknionej śmiertelności) o możliwość „ucieczki” przed materialnym niebytem (ucieczki „Z życiem” przed śmiercią organiczną)? I nie chodzi tu o spryt żaden, gdyż natury stworzenia, któremu zapisane jest umarcie, żadnym podstępem zmienić się nie da (gdyby nawet pokładać nadzieję w technologicznym sklonowaniu siebie). 
i przyjętej według dowolnie wybranego aktem własnej woli nominału seksualności lub - jak mówią konstruktywiści gender - nominału tożsamości płciowej kulturowo swobodnie wybranej; niezgodnie z zastanym w sobie upłciowieniem cielesnym ( $\mathrm{w}$ akcie świadomej negacji „Zastanej” w sobie płciowości cielesnej jako nominalnie różnej, a więc niezgodnej z wymyśloną tożsamością seksualną),

c) czy człowiek, który mimo upłciowienia naturalnego neguje fakt swej płci cielesnej (dokonuje dziwnej operacji myślowej na bycie, z zamiarem wyzbycia się płciowości: „puszczenia” cielesnej płciowości w niebyt), a tym samym unieważnia pojęcie człowieka jako bytu dualnie upłciowionego cieleśnie. Człowiek w wersji konstruktywistycznej queer - wyzbywający się płciowości - przez zniesienie płciowej różnicy cielesnej (ontyczne „zatarcie” płciowości uwidocznione zostaje w aseksualnym kostiumie), jako bezpłciowa postać (post-płciowa) określa tożsamość cielesną, mimo wyrażonej niezgody na płciowość, homoseksualnością dowolnej ekspresji.

Który spośród trzech jest prawdziwy?

Obie wersje człowieka: gender i queer upodabnia nieheteroseksualna tożsamość istoty ludzkiej. Ideologia gender znosi prawdę metafizyczną o męskości i kobiecości człowieka; posługuje się wprawdzie nominałem kobiecości i męskości, lecz nie odnosi go do rzeczywistej natury płciowo-cielesnej istoty ludzkiej, tylko społecznie potworzonej roli homoseksualnej postaci. $Z$ istoty swej natury mężczyzna może ukształtować siebie jako kobieta, a kobieta pozostająca w związku lesbijskim może ukształtować siebie jako mężczyzna. Relacja homoseksualna, będąca fikcją metafizyczną - jako rzekome, a nie rzeczywiste, wspólistnienie kobiety i mężczyzny - spełnia się seksualnie, ale prokreacyjnie dokonać niczego nie może; nie może zatem uczestniczyć we wspólnocie życia, ani też - z moralnego punktu widzenia - przyjąć odpowiedzialności za kultywację życia.

Ideologia queer zaprzecza płciowości, nawet tej, jaką afirmuje homoseksualność ideologii gender. Nie posługuje się nominałem kobiecości i męskości, gdyż seksualności nie wyprowadza z płciowości; queer jest seksualistą, a nie płciowcem wersji homo, co należy rozumieć, że kreacja gender jest afirmacją homopłciowości, a queer - homoseksualności.

Homoseksualność obu wersji post-człowieka jest metafizycznie nieprawdziwa (ontycznie fałszywa), gdyż pozostaje w sprzeczności z ideą płci człowieka w męskości i kobiecości.

Postać gender należy do związku jednopłciowego (homo), przez co wyzbywa się heteroseksualności, a tym samym niweczy możność prokreacyjną. W konsekwencji wyzbycia się prokreacyjności „,homopłciowiec” definitywne traci możność rodzicielską - nie zostanie ojcem ani matką. Choć ktoś okazał mu rodzicielstwo, to on wykazać się rodzicielstwem naturalnym obiektywnie nie może; pozostając w związku jednopłciowym, nie jest w stanie powołać potomka do życia. 
Postać queer jest wieloseksualna (seksualnie różnokształtna), wyzbywa się płciowości naturalnej przez jej negację, czym niweczy możność prokreacyjną.

Obie postaci gender i queer zatracają, z dwóch różnych powodów, możność prokreacyjną: gender przez pozostawanie w związku homopłciowym, a queer - apłciowym i dowolnie seksualnym. Upodabnia je niemożność prokreacyjna, a w konsekwencji odrealnienie rodzicielskie. Nie mogąc być ojcem i matką, muszą się ,podszyć”, stworzyć pozór w rodzicielstwie i rodzinności. Nie chcą spełnić się prokreacyjnie, a oświadczają, że chcą ,dać” dziecku cudzemu (adoptowanemu) życie. W konsekwencji wytworzone relacje pozoru - wobec siebie i wobec cudzego dziecka - nazywają rodziną. I nie to jest złem moralnym, że zatajają przed dzieckiem prawdę o męskim ojcostwie i kobiecym macierzyństwie, jako jedynie realnej heterodualności: przez heteropłciowość i heterorodzicielskość, lecz przez założenie dziecku blokady epistemicznej, która uniemożliwia czystemu rozumowi poznanie prawdy o własnej, przyrodzonej płciowości w heteroseksualnej realności; dziecko samoistnie odczuwa konieczność podawania się za „obcego" w sobie (kim się realnie przez płciowość nie jest) - a więc uczestniczenia w kłamstwie dorosłych.

Niezależnie od rodzicielskich uroszczeń gender i tak jest przebierańcem seksualnym: gra rolę męską w postaci realnie kobiecej lub rolę kobiecą, będąc fizycznie mężczyzną. Poświadcza nieprawdę przez błędne odniesienie rozumu do realnego upłciowienia własnego ciała. Pozoruje tym samym udział we wspólnocie życia. A prawdą jest, że przez niemożność prokreacyjną nie jest powiernikiem życia oraz że unicestwia dalszą przyczynowość prokreacyjną, kiedy zataja przed dzieckiem adopotowanym prawdę o powołaniu mężczyzny i kobiety do udziału w rodzicielstwie - o jego odpowiedzialności za ciągłość życia.

\section{Wnioski}

1. Prawo życia to ius naturalis. Prawem naturalnym człowieka jest życie, bo życie zależy od tego, że ciało żyje. Ale nie dla życia i nie dla ciała we wspólnocie żyje człowiek, i też nie jest tak, że jako byt osobny, a pozostający w relacji nieoddzielności, ma podlegać uprzedmiotowieniu poprzez użycie jego „,konkretu substancjalnego" jako środka do celu, który wyłącza go z drogi rozwoju jako osoby. Wspólnota życia, będąca bytem relacyjnym, a więc substancjalnie niekonkretnym, nie jest ważniejsza od osoby.

2. Nieoddzielność istnienia człowieka jest konieczna. Tylko wtedy przynosi korzyść prawdziwą, kiedy racją jego istnienia staje się dobro drugiej osoby. Człowiek staje się osobą, kiedy właśnie w relacji nieoddzielności raczy się dobrem prawdy poznania, uwzniośla dobrem miłości, udziela dobra godziwego i wytwarza dobro piękności. 
A zatem miłość jest prawem naturalnym człowieka, jeśli przez jej czynne urealnienie człowiek staje się osobą; co staje się dobrem dla osoby jako bytu nieoddzielnego, choć osobnego, jest tak samo korzystne dla każdego.

3. By życie społeczne mogło się dokonać podług ideału osoby, trzeba by życie jako życie zostało prokreacyjnie powierzone nienarodzonemu. A zatem prawem naturalnym człowieka jest powiernictwo życia cielesnego.

4. Nie jest równy wobec prawa życia, kto wyrzekłszy się prokreacyjności, jako zasady powiernictwa życia potomkowi, z seksualności uczynił hecę życia dla siebie. Wyrzeczenie się płci, negacja płciowości, przekreśla prokreacyjność, pozostawia natomiast osobnikowi queer seksualność - doposażoną w artefakty wzmagające ekspresję lesbijską, gejowską, transseksualną i biseksualną.

Wyrzeczenie się jednego skutkuje drugim: wyjęciem siebie spod odpowiedzialności za utrzymanie ciągłości międzypokoleniowej życia, a ostatecznie zastąpieniem udziału w kulturze życia, paradowaniem w szyku seksualnego hedonizmu - będącym przez obsceniczność queer moralnym zboczeniem z drogi powołania ku celebracji świętości życia.

5. Nie jest też równy wobec prawa życia, kto albo nie określa tożsamości płciowej (przypadek gender) w uzgodnieniu z naturą swej płciowej jednoznaczności (męskość lub kobiecość), albo wyzbywszy się w ogóle tożsamości płciowej (przypadek queer) miałby przygarnać adopcyjnie cudzego potomka. Kto nie potrafi siebie poznać adekwatnie do specyfiki naturalnego upłciowienia - zafałszowując prawdę o tożsamości płciowej - lub w ogóle pozostaje dla siebie płciowo bezimienny (bezpłciowy choć seksualny w wersji homo) - nie jest zdolny, by wzbudzić u potomka $\mathrm{z}$ adopcji prawdziwościowe poznanie tożsamości płciowej. Tym samym nie ma prawa moralnego do przetrzymywania potomka cudzego $\mathrm{w}$ anty-kulturze fałszu cielesno-płciowego czy post-kulturze pozapłciowej homoseksualności.

6. Z nieprawości seksualistów nie wyłoni się prawdomówność adopto-potomka, gdy ten będzie oznajmiał „prawdę" o otrzymanej tożsamości płciowej; będzie tak samo uchybiał prawdzie logicznej o płciowości, jak nie było mu dane poznanie potocznej prawdy o męskości i kobiecości. I nie to będzie złem, że przez egoizm pseudo-rodziców nie poznał człowieka w jego zgodności z ideą siebie - jak prawdziwie wygląda człowiek w męskości i kobiecości, ojcostwie i macierzyństwie - lecz że zablokowany zostanie w prokreacyjności. Adopto-potomek seksualistów nie dostąpi udziału we wspólnocie życia. Ktoś go życiem obdarował, a ten - gdyby nawet chciał - nie będzie umiał długu życia spłacić; życie odziedziczył, lecz nie potrafił życia powierzyć. Gdyż i tego nie nauczyli go seksualiści wersji homo, że spoczywa na nim obowiązek powierniczy; nie nauczyli, gdyż sami nie wiedzieli . ${ }^{11}$

${ }^{11}$ Schemat tego rozumowania, w znaczeniu formalnym, zawdzięczam Rogerowi Scrutonowi (Scruton, Roger. 2014. Jak być konserwatystą? Poznań: ZYSK i S-KA, 323). 
7. Prawo życia zakłada prokreacyjność, a tym samym ojcostwo mężczyzny i macierzyństwo kobiety. Życie jako życie ustaje, kiedy warunek rodzicielstwa nie może być spełniony. Potomek adoptowany - poddany homoseksualnej narracji o możliwości dowolnego ,skonstruowania” tożsamości płciowej lub w ogóle odwiedziony od upłciowionej cielesności - nie rozpozna się prawdziwościowo w rodzicielstwie, gdyż nie będzie mu dane rozpoznanie pierwiastka prawdziwego „ojcostwa” i „macierzyństwa” w falsyfikatach przebierańców. Fałszywy płciowo seksualista - gender i queer - nie może być jednocześnie prawdziwy jako „rodzicielski” opiekun.

8. Od pradziejów istnienia „człowieka rozumu uczciwego” kostium jest znakiem jego tożsamości płciowej: a) potomka dorosłych, którym przysługuje przydatek szatki z bieli - na znak przynależności do wspólnoty życia w świętości Bożej; oraz przydatek ubranka w niebieskim dla chłopca $\mathrm{i}$ w różowym dla dziewczynki ${ }^{12}$ - na znak przynależności do rodziny człowieczej z przeznaczeniem ku umacnianiu się w męskości i kobiecości, a w perspektywie społecznego dojrzewania ku ojcostwu i macierzyństwu; b) dorosłych, którym przysługuje - mimo zmienności dziejowej wzorów ukostiumowienia - dwojako zróżnicowane odzienie, uwzględniające ich płciową odmienność.

9. „Człowiek rozumu nieuczciwego”, który uchybia swym błądzącym poznaniem prawdzie metafizycznej o sobie, nie przyjmuje, jaki byt człowieczy jest w jego istocie i istnieniu; konstruuje byt po swojemu, jakby żywił przekonanie, że myśleniem może byt stworzyć wedle uznania. Takiemu przeświadczeniu ulegają konstruktywiści poddający się powidokowi ontologicznemu. Konstruktywny akt „stworzenia” post-człowieka w wersji homoseksualnej gender i queer muszą poprzedzić dekonstrukcją prawdziwościowego pojęcia człowieka - co urąga realizmowi ontologicznemu oraz racjonalności czystego rozumu. Dekonstrukcja pojęcia człowieka zostaje odniesiona przez postmodernistycznych konstruktywistów do wszelkich znaków dziejowego konserwatyzmu. Kostium konserwujący znakową prawdę o człowieczej męskości i kobiecości, a w konsekwencji upłciowieniu ku prokreacyjności jako zasadzie konstytuowania wspólnoty życia, zostaje zanegowany, a w obyczajowości ulicznej performy obscenicznie wyszydzony. W pierwszym akcie łagodnego buntu wobec natury fizyczności kostium tradycyjny zostaje odrzucony (jak niechciany znak rzeczywistej tożsamości płciowej), a w drugim, skrajnie radykalnym, zastąpiony zostaje kreacją symbolizującą seksualność queer. Post-kostium seksualisty queer ma oznajmiać kolorem tęczy, że wiele jest różno-

12 Od stosunkowo niedawna kolory niebieski i różowy są kostiumowym znakiem tożsamości płciowej dziecka. Dzieje ukostiumowienia płci dziecka wymagają oddzielnych studiów, nie tylko w aspekcie znaku-koloru. 
ści seksualnych, które mogą być celebrowane, a żadna z nich nie nawiązuje do oryginału; jest kopią bez oryginału.

A to znaczy, że kto tak myśli, popada w pułapkę sprzeczności logicznej. Bo gdyby nie ów realny oryginał hetero-płciowości, ulokowany w życiodajnym rodzicielstwie jego ojca i matki, seksualista wersji homo nie mógłby być ich dzieckiem jako dziedzic życia. Chełpliwy i krzykliwy post-człowiek: otrzymał życie w darze dzięki oryginałowi męskości i kobiecości własnych rodziców, a sam sprzeniewierzył się idei życia i na dodatek zdekonstruował, z udziałem ideologów postmodernizmu, pojęcie rodzicielskiego dawcy życia. Tęczowym znakiem kabotyńskiego kostiumu poświadczył - nieświadomy pułapki metafizycznej, jaką na siebie zastawił - że jest marnym falsyfikatem hetero-płciowego oryginału.

\author{
THE MASTERY OF GENDER AND THE DECONSTRUCTION \\ OF THE COSTUME AS A SIGN OF GENDER IDENTITY. REFLECTION \\ OF A HUMANIST, PHYSICAL CULTURE EDUCATOR
}

\title{
SUMMARY
}

The gender and queer ideology deconstructs the concept of a human being. The costume that preserves the symbolic truth about human masculinity and femininity, and as a consequence - about gendering towards procreation as the principle of constituting a community of life - is denied (gender) or replaced with a creation symbolizing asexual sexuality (queer). Both forms of gender and queer lose their ability to procreate for two different reasons: gender by being in a homosexual relationship, and queer by being sexually and freely sexually active. They are made similar to their reproductive inability and, consequently, parental unreal. Meanwhile, the law of life presupposes procreation, and thus paternity of a man and motherhood of a woman. Life as life ceases when the condition of parentage cannot be met. In the essay, the source of these statements is the natural law (ius naturalis), which is a universal premise for judging the deeds of both forms of postmodernity as contradicting the idea of life.

Keywords: sexual identity, ideology gender and queer, natural law, procreation

Słowa kluczowe: tożsamość płciowa, ideologia gender i queer, prawo naturalne, prokreacja 


\section{BIBLIOGRAFIA}

Dogiel, Gerard. 1992. Metafizyka. Kraków: Instytut Teologiczny Księży Misjonarzy.

Fukuyama, Francis. 2004. Koniec człowieka. Konsekwencje rewolucji biotechnologicznej. Kraków: Znak.

Godin, Christian. 2004. Koniec ludzkości. Kraków: Wydawnictwo WAM.

Jędraszewski, Marek. 2019. Pamięć o bohaterskich czynach powstańców jest naszym zobowiązaniem. Dostęp: 01.08.2019. https://diecezja.pl/aktualnosci/pamiec-o-bohaterskich-czynachpowstancow-jest-naszym-zobowiazaniem/.

Nietzsche, Friedrich. 2006. Wiedza radosna. Warszawa: Wydawnictwo Zielona Sowa.

Olczyk, Maciej. 2014. Eksperyment gender. Od teorii równości płci do ideologii polimorfizmu ekspresji seksualnej. Gniezno: Gaudentinum.

Olczyk, Maciej. 2017. Kobieta i mężczyzna kustoszami Ewangelii życia w kontekście eksperymentu społecznego gender. Teologia i Moralność , vol. 12, nr 2 (22).

Scruton, Roger. 2014. Jak być konserwatysta ?. Poznań: Wydawnictwo Zysk i S-ka.

Sitchin, Zecharia. 2018. Kroniki Anunnaki. Warszawa: Wydawnictwo Amber.

Szewczak, Janusz 2020. Idiotokracja, czyli zmowa głupców. Kraków: Biały Kruk.

Zaremba-Bielawski, Maciej. 2011. Higieniści. Z dziejów eugeniki. Wołowiec: Wydawnictwo Czarne.

Andrzej Pawłucki - prof. dr hab., profesor zwyczajny w Zakładzie Pedagogiki Kultury Fizycznej Akademii Wychowania Fizycznego we Wrocławiu. Wykłada pedagogikę sportu i olimpizmu, pedagogikę zdrowia, filozofię kultury fizycznej i metodologię badań społecznych. Laureat głównej nagrody Ministra Nauki i Szkolnictwa Wyższego; e-mail: andrzej.pawlucki@awf.wroc.pl 